\title{
Extended single stage distally based sural flap for reconstruction of mid leg defects
}

\author{
Mahfouz Shehata, MD, MRCS; Hany Mohamed, MD; Emad Salah Ibrahim, MD
}

\author{
Plastic Surgery Unit, General Surgery Department, \\ Zagazig University, Sharkia, Egypt.
}

Background: Reconstruction of middle third soft tissue defects of the legs have been a challenge to the plastic surgeons.

Patients and methods: We report 20 cases in which the extended single stage distally based sural flap was used to reconstruct soft tissue defects at the middle third of the leg over 2 year period.

Result: Complications occurred in 4 patients (20\%). Two patients suffered surgical site infections and another two experienced distal partial flap necrosis but all flaps survived. We can conclude that the flap is a good option for reconstruction of middle third leg defects of the leg. It has constant and reliable blood supply without sacrifice neither major vessel nor nerve.

Key words: Single stage, extended distally based sural flap, mid third leg defects, reconstruction.

\section{Introduction:}

Reconstruction of soft tissue defects of the middle third of the leg has remained a persistent challenge to the reconstructive surgeons. This area is liable to bone exposure after traumas due to its thin skin, less amount of local tissue and poor vascularity. ${ }^{1}$ Many techniques are available for leg reconstruction but each technique has its inherent limitations and costs. Free flap is a good option but it has the disadvantage of being a sophisticated and lengthy procedure, involving a high price, advanced equipment and a microsurgical team.2,3 Local muscle flaps like soleus or gastrocnemius flaps are also described for middle third defects but might yield unsatisfactory cosmetic and functional results. ${ }^{2,4}$ Since $1^{\text {st }}$ described by Masquelet et al, $1992^{5}$ distally based sural flap has been limited to defects in the distal third of the tibia, around the ankle and foot. ${ }^{6,7}$ This study is to evaluate the outcome of extended single stage distally based sural flap for reconstructing mid leg post traumatic defects.

\section{Patients and methods:}

From December 2011 to Jan 2014 a total of 20 single stage extended distally based sural flaps had been done for reconstruction of post traumatic soft tissue defects at the middle third of the leg with exposed tibias. All patients were males with average age of 30 years (range from 17-50 years). The length of the flap ranged from 28 to $34 \mathrm{~cm}$ (average $31.2 \mathrm{~cm}$ ) and the width at the widest point ranged from 10 to $15 \mathrm{~cm}$ (average,12 $\mathrm{cm}$ ) Table (1). The average time of follow up was 9 months (ranged from 3 to 18 months). All patients were firstly operated upon by orthopedic surgeons where they applied external fixations. Duplex study was then done for detection of patent peroneal perforators but was not mandatory.

\section{Surgical procedure:}

The patient was placed in the lateral decubitus position, under general anesthesia, after marking the axis of the flap, which was the course of the medial sural nerve. The flap was outlined according to the size of the defect and distance from it. The superior edge 
of the flap was about one inch just distal to the knee crease. The pivot point was $5 \mathrm{~cm}$ above the tip of the lateral was malleolus along the axis of the flap (this level determined by position of last perforator). The incision was made along the superior border of the flap. At mid-calf, the sural nerve and lesser saphenous vein were identified suprafascially. The sural nerve, artery, and lesser saphenous vein were divided and ligated, and was included within the flap. The entire flap was elevated and dissected subfascialy from the proximal to distal end. Then a direct incision between the donor site and the recipient site, rather than a subcutaneous tunnel was done. The flap was then transposed and sutured to the recipient site and the donor was then covered by skin graft from the same thigh Figures $(\mathbf{1}, \mathbf{a}, \mathbf{b})$.

After the operation all patients were advised to elevate their legs and also splint immobilization was recommended for 2 weeks.

The stitches were removed after 2 weeks.

\section{Results:}

We performed 20 extended distally based sural flaps for 20 patients with soft tissue defects at mid leg level either post traumatic or post gunshot. The success rate was 100\% with all flaps survived Figure (1,c). Only two flaps suffered distal necrosis that were treated conservatively and another two developed surgical site infections and were also successfully treated with antibiotic therapy according to wound swab culture and sensitivity Table (1). This flap provided a satisfactory coverage for such defects in all patients. Postoperatively we noticed slight venous congestion in some flaps but these resolved with leg elevation alone. The removal of sural nerve within the flap caused loss of sensation over the outer foot but surprisingly improvement was noted starting $6^{\text {th }}$ months post surgery.

\section{Discussion:}

An ideal flap should be easy to raise, reliable, not dependent on microsurgery and should not sacrifice major vessel or major nerve. ${ }^{8,9}$
This flap satisfies the previous criteria and covers the mid leg defect with satisfactory result.

It is versatile and can reach the distal third, heel, dorsum of foot and middle third of the leg. $7-11$

This flap has long and narrow pedicle and a wide arc of rotation because its vascular axis has the longest direct artery of the posterior calf and the strongest peroneal perforator at its pivot point. ${ }^{15}$

The local versus free flaps for covering defects in mid leg involves long operative time, sophisticated instruments, a need for well trained microsurgery team and high equipment cost of the later. ${ }^{16,17}$

Local muscle flap like gastrocnemius or soleus total or hemi flaps has proven to be another option for covering defects in this area however because of local contusion of soft tissues after trauma it is not always healthy.Another drawback is the limited muscle size in comparison to defect size that sometimes very big, beside the compromise of limb function. ${ }^{16,18,19}$

In this study we presented the reversed sural flap but not only taking the distal and middle third of the leg but also the proximal third to cover a big size defect in mid leg.

The idea of taking the proximal third of the leg within the flap has been reported. ${ }^{20}$ They used it for foot defects on 13 patients without any total flap loss taking their proximal incision 1-2 cm from knee crease. The upper limits of the flap's dimensions have been best explored by Ayyappan and Chadha, 2002 when they reported that the flap can be extended proximally to include the entire upper third of the leg posteriorly with a pivot point only 4 to $5 \mathrm{~cm}$ proximal to the lateral malleolus but also their work was on heel defects. ${ }^{21}$

In this study there was no tunneling, wide segment of tissues around the pedicle of the flap and the skin was also kept on the flap. All these modifications aimed at decreasing the venous congestion, avoid flap kink and excessive flap tension so only two cases developed partial distal necrosis and this proved to be effective in other series. ${ }^{22-} 24$ 

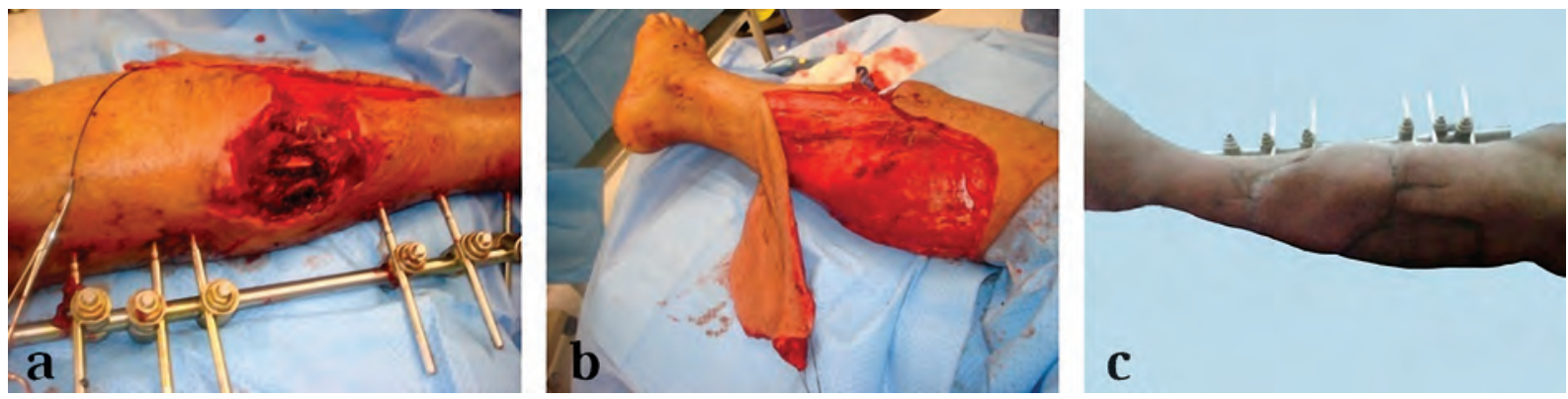

Figure (1): (a) After external fixator application, (b) The extended reversed sural flap raised, (d) Post operative flap completely viable.

Table 1: Patient's demographics, flaps dimensions and complications.

\begin{tabular}{|l|l|l|l|}
\hline Patient nom & age/sex & length $\times$ width & complication \\
\hline 1 & 30 & $13 \times 32$ & ----- \\
\hline 2 & 22 & $11 \times 30$ & ----- \\
\hline 3 & 17 & $10 \times 28$ & ----- \\
\hline 4 & 45 & $14 \times 34$ & partial necrosis \\
\hline 5 & 34 & $14 \times 34$ & ----- \\
\hline 6 & 20 & $10 \times 29$ & ----- \\
\hline 7 & 48 & $14 \times 34$ & ----- \\
\hline 8 & 32 & $12 \times 32$ & surgical site infection \\
\hline 9 & 30 & $12 \times 32$ & ----- \\
\hline 10 & 18 & $10 \times 28$ & ----- \\
\hline 11 & 50 & $15 \times 34$ & partial necrosis \\
\hline 12 & 24 & $12 \times 30$ & ----- \\
\hline 13 & 25 & $11 \times 30$ & ----- \\
\hline 14 & 40 & $13 \times 33$ & surgical site infection \\
\hline 15 & 22 & $14 \times 33$ & ----- \\
\hline 16 & 18 & $10 \times 29$ & ----- \\
\hline 17 & 24 & $10 \times 30$ & ----- \\
\hline 18 & 46 & $12 \times 32$ & ----- \\
\hline 19 & 20 & $10 \times 28$ & ----- \\
\hline 20 & 35 & $12 \times 32$ & ----- \\
\hline
\end{tabular}

This flap was a single procedure so it avoided the burden of long hospital stay and two stage procedures of either delayed or cross leg reverse sural flaps described in other studies. ${ }^{21,25-27}$

Distal flap necrosis was the most encountered complication that developed in two patients (10\%) but in other series the rate of flap necrosis were $15 \%, 16 \%, 22 \% 7,28,29$ and the low incidence in this study might be due to wide pedicle size and less amount of kinking.
In this study the sural flap was taken in the centre of the flap so affecting the sensation at outer border of the leg but with noted improvement in sensation with time and this also reported in other studies. ${ }^{30,31}$

\section{Conclusion:}

Extended single stage distally based sural flap is a reliable and easy option for reconstructing mid leg defects with very less morbidity. It does not involve sacrifice of major vessel or nerve or functional 
impairment.

\section{Reference}

1- Hollier L, Sharma S, Babigumira E, Klebuc M: Versatility of the sural fasciocutaneous flap in the coverage of lower extremity wounds. Plast reconstr Surg 2002; 110: 1673-1679.

2- Shin JS, Kim HH: A novel reconstruction technique for the knee and upper third of leg: J Plast Reconstr Aesthetic Surg 2006; 59: 929-934.

3- Swartz WM, Mears DC: The role of free-tissue transfers in lower-extremity reconstruction. Plast Reconstr Surg 1985; 76: 364-373.

4- Rajacic N, Gang RK, Darweesh M, Abdulf $\mathrm{N}$ : Reconstruction of soft tissue defects around the knee with the use of the lateral sural fasciocutaneous artery island flap. Eur J Plast Surg 1999; 22(1): 12-16.

5- Masquelet AC, Romana MC, Wolf FG: Skin island flaps supplied by the vascular axis of sensitive superficial nerves: Anatomic study and clinical experience in the leg. Plast Reconstr Surg 1992; 89:1115-1121.

6- Touam C, Rostoucher P, Bhatia A, Oberlin C: Comparative study of two series of distally based fasciocutaneous flaps for coverage of the lower one-fourth of the leg, the ankle, and the foot. Plast Reconstr Surg 2001; 107(2): 383-392.

7- Akhtar S, Hameed A: Versatility of the sural fasciocutaneous flap in the coverage of lower third leg and hind foot defects. $J$ Plast Reconstr Aesthet Surg 2006; 59(8): 839-845.

8- Donsaki PK, Fogdestam I: Distally based fasiocutaneous flap from sural region: A preliminary report. Scand J Plast Reconstr Surg 1983; 17:191-196.

9- Hong G, Steffen S, Wang FB: Reconstruction of the lower leg and foot with revrse pedicle posterior tibial fasciocutaneous flap. $\mathrm{Br} J$ Plast Surg 1989; 42: 512-516.

10- Morgan K, Bantigan CO, Field CJ, Paden M: Reverse sural artery flap for the reconstruction of chronic lower extremity wounds in high-risk patients. The Journal of Foot \& Ankle Surgery 2006; 45(6): 417-423.

11- Singh S, Naasan A: Use of distally based superficial sural island artery flaps in acute open fractures of the lower leg. Ann Plast Surg 2001; 47: 505-510.

12- Hsieh CH, Liang CC, Kueh NS, Tsai HH,
Jeng SF: Distally based sural island flap for the reconstruction of a large soft tissue defect in an open tibial fracture with occluded anterior and posterior tibial arteries. A case report. Br J Plast Surg 2005; 58: 112-115.

13- Rajacic N, Darweesh M, Jayakrishnan K, Gang RK, Jojic S: The distally based superficial sural flap for reconstruction of the lower leg and foot. Br J Plast Surg 1996; 49: 383-389.

14- Chen SL, Chen TM, Chou TD, Chang SC, Wang HJ: Distally based sural fasciomusculocutaneous flap for chronic calcaneal osteomyelitis in diabetic patients. Ann Plast Surg 2005; 54: 44-48.

15- Noack N, Hartmann B, kuntscher MV: Measures to prevent complications of distally based neurovascular sural flaps. Ann Plast Surg 2006; 1: 37-40.

16- Verhelle N, Vranchx J, Vanden HB, Heyman SV: Bone exposure in the leg: Is a free muscle flap mandatory? Plast Reconstr Surg 2005; 116: 170-177.

17- Follmar KE, Baccarani A, Baumeister SP, Levin LS, Erdmann D: The distally based sural flap. Plast Reconstr Surg 2007; 119(6): 138-148.

18- Misra A, Niranjan NS: Fasciocutaneous flaps based on fascial feeder and perforator vessels for the defects in the patellar and peripatellar regions. Plast Reconstr Surg 2005; 115: 1625-1632.

19- Mancoll JS, Phillips LG: Pressure sores. In: Plastic surgery, indications,operations and outcomes. Achauer BM, Eriksson E, Guyuron B, Coleman 111 JJ, Russel RC, Vander CA (eds): Volume 1, Part 2, Chapter 30, Mosby, St. Louis, London, 2000; p 447.

20- Mohammadkhah NI, Motamed S, Hosseini SN, Hallajmofrad RZ, Abdolzadeh M: Complex technique of large sural flap: An alternative option for free flapin large defect of the traumatized foot. Acta Medica Iranica 2011; 49(4): 195-200.

21- Ayyappan T, Chadha A: Super sural eurofasciocutaneous flaps in acute traumatic heel reconstructions. Plast Reconstr Surg 2002; 109 (7): 2307-2313.

22- Kececi Y, Sir E: Increasing versatility of the distally based sural flap. The Journal of Foot \& Ankle Surgery 2012; 51: 583-587.

23- Yilmaz M, Karatas O, Barutcu A: The distally based superficial sural artery island flap: Clinical experiences and modifications. Plast Reconstr Surg 1998; 102: 2358-2367. 
24- Vergara AE: Distally-based superficial suralneurocutaneous flap for reconstruction of the ankle and foot in children. J Plast Reconstr Aesthet Surg 2009; 62(8): 1087-1093.

25- Korse R, Morden C, Sanli C: The use of expanded reverse sural artery flap in lower extremity reconstruction. The Journal of Foot and Ankle Surgery 2010; 50: 695-698.

26- Kenser U, Bach AD, Polykandriotis E, Kopp J, Horch RE: Delayed reverse sural flap for staged reconstruction of the foot and lower leg. J Plast Reconstr Surg 2005; 116(7): 1910-1917.

27- Atiyeh B S, Al-Amm CA, El-Musa KA, Sawwaf AW, Musharafieh RS: Distally based sural fasciocutaneous cross-leg flap: A new application of an Old Procedure. Plast Reconstr Surg 2003; 111 (4): 1470-1474.

28- Belfkira F, Forli A, Pradel P, Guinard
D, Moutet F: Distally based sural neurocutaneous flap: Clinical experience and technical adaptations. Report of 60 cases. Ann Chir Plast Esthet 2006; 51(3): 199-206.

29- Patel KB, Bartholoma SV, Wong MS, Stevenson TR: Distally based sural lesser saphenous neuro-veno-adipo-fascial (NVAF) flap for reconstruction in the foot: Lessons learned. Foot and Ankle Surgery 2010; 16: 79-83.

30- Leforum B, Caye N, Ponnier M: Distally based sural fasciocutaneous flap: Anatomic study and application for filling leg or foot defect. Plast Reconstr Surg 2001; 107: 67.

31- Park JS, Roh SG, Lee NH, Yang KM: Versatility of the distally-based sural artery fasciocutaneous flap on the lower leg and foot in patients with chronic disease. Arch plast Surg 2013; 40(3): 220-225. 